\title{
Effects of Number and Rate of Goat Manure Application on Soil Properties, Growth and Yield of Sweet Maize (Zea mays L. saccharata Strut)
}

\author{
D. F. Uwah ${ }^{1} \&$ V. E. Eyo ${ }^{1}$ \\ ${ }^{1}$ Department of Crop Science, University of Calabar, P.M.B 1115, Calabar, Nigeria \\ Correspondence: D. F. Uwah, Department of Crop Science, University of Calabar, P.M.B 1115, Calabar, Nigeria. \\ E-mail: dfu55@yahoo.ca
}

Received: July 17, 2014 Accepted: September 2, 2014 Online Published: October 9, 2014

doi:10.5539/sar.v3n4p75 URL: http://dx.doi.org/10.5539/sar.v3n4p75

\begin{abstract}
Alternative sources of plant nutrients have now become highly imperative especially for vegetable crop production in Nigeria. Due to the escalating costs, environmental and health problems associated with excessive use of inorganic fertilizers on continuously cropped fields, there is a need for more research on the use of organic manures and residues. A field experiment was conducted in the late growing season from September to December, 2012 in Calabar, a humid forest agroecology in south eastern Nigeria to evaluate the effects of two types of goat manure (GM) application (single and double split doses), five rates of GM $(0,5,10,15$ and $20 \mathrm{t}$ $\mathrm{ha}^{-1}$ ) and $400 \mathrm{~kg} \mathrm{ha}^{-1}$ NPK fertilizer $\left(120: 60: 60 \mathrm{~kg} \mathrm{ha}^{-1}\right)$ rate on soil chemical properties and agronomic performance of sweet maize (Zea mays L. saccharata Strut). Factorial combinations of the treatments were fitted into a randomized complete block design with three replications. The application of GM significantly $(\mathrm{P} \leq 0.05)$ increased soil $\mathrm{pH}$, organic matter $(\mathrm{OM})$ content, total $\mathrm{N}$, available $\mathrm{P}$, exchangeable $\mathrm{K}, \mathrm{Ca}, \mathrm{Mg}$ and the cation exchange capacity (CEC) status of the soil. Soil exchangeable acidity (EA) was reduced from 1.76 to $0.64 \mathrm{cmol}$ $\mathrm{kg}^{-1}$ at $20 \mathrm{t} \mathrm{ha}^{-1} \mathrm{GM}$ rate. The $20 \mathrm{t} \mathrm{ha}^{-1}$ also recorded the highest values for soil $\mathrm{pH}, \mathrm{OM}, \mathrm{P}, \mathrm{Ca}, \mathrm{Mg}$ and CEC, while the values for residual N and K peaked at the NPK fertilizer treatment. The double split application of GM recorded higher values for growth and yield attributes, and increased soil properties than the single application. Growth and yield parameters such as plant height, number of leaves, leaf area index (LAI), total dry matter (TDM), number and weight of grains/ear and total grain yield were significantly $(\mathrm{P} \leq 0.05)$ increased by GM and NPK fertilizer treatments. The values obtained for all growth and yield parameters except LAI at the $20 \mathrm{tha}^{-1}$ GM rate were not significantly different from those at the NPK fertilizer treatments. The application of 5, 10,15 and $20 \mathrm{t} \mathrm{ha}^{-1} \mathrm{GM}$, and NPK fertilizer significantly increased TDM by 11.9, 74.3, 91.9, 106.2 and 104.6\%; weight of grains/ear by $16.5,54.6,61.4,100.6$ and $94.4 \%$ and total grain yield by $46.9,111.7,121.0,127.2$ and $140.1 \%$ respectively, compared with the control treatment. The interactions between number of applications and rates showed that split applying GM at $20 \mathrm{t} \mathrm{ha}^{-1}$ maximized TDM, weights of whole and dehusked green ears and total grain yield compared to other GM rates, hence it is recommended.
\end{abstract}

Keywords: NPK fertilizer, sweet maize, goat manure, rate, soil properties, yield

\section{Introduction}

Sweet maize (Zea mays L. saccharata Strut), one of the maize types containing 13-15\% sugar in the immature grains, is a mutant of the dent and flint sub-species (Bhatt, 2012). It is mostly grown in the United States of America, East Asia, and some European countries and has become popular among the higher income groups in African countries (Badu-Apraku \& Fakorede, 2006). In Nigeria, sweet maize is gradually becoming an important vegetable crop since it forms a useful ingredient in the preparation of salad, fried rice and other dishes both at home and in restaurants.

The production of sweet maize has intensified in market gardens in the country due mainly to increasing demand and partly to augment the income of peasant farmers dwelling in the outskirts of large cities. Organic matter and nutrient depletion are the major causes of low crop yield under intensive cropping. Continuous cropping as a result of scarcity of land, removal of crop residues after cropping for feeding livestock, nutrient depletion through erosion and leaching leading to increased soil acidity, have generally reduced the productive capacity of 
the arable land in Nigeria (Akinrinde \& Obigbesan, 2000; Brady \& Weil, 2008). To achieve food security for the rapidly expanding population in Nigeria will entail making deliberate efforts at promoting the judicious utilization of animal manures and organic residues for crop production. Soil enhancing benefits from these manures in addition to those from macro and micro nutrients supply, are linked to the organic matter that improves soil structure, moisture relations and increases mobility of $\mathrm{P}, \mathrm{K}$ and micro nutrients and stimulates microbial activities (Maerere et al., 2001; Garg \& Bahla, 2008).

Many farmers that apply animal manures lack the scientific knowledge for appropriate rate, timing and number of applications, method of application and storage techniques to retain nutrients. Timing of nutrient application is guided by some basic considerations which include nutrient availability when crops need it, avoiding waste and enhancing nutrient use efficiency (Brady \& Weil, 2008). Although goat manure (GM) is readily available on most small holders' vegetable farms and home gardens in south eastern Nigeria, second only to poultry manure in terms of availability its use has received little research attention. There is a dearth of information on appropriate number of applications and the right proportion for optimum performance of sweet maize by farmers. Previous research findings available indicate that farmers still apply GM a week or two before planting or soon after planting or whenever it was available. Also the effects of the inconsistent number and rate of application which may subsequently affect crop performance has not been well documented. Furthermore, most studies on utilization of animal manures emphasize on crop yield without relating the yield to availability of nutrients in the soil.

Increased crop growth rate, yield, ability to tolerate stressful conditions and product quality in relation to application of goat manure have been widely reported (Maerere et al., 2001; Awodun et al., 2007; Akanni \& Ojeniyi, 2008; Odedina et al., 2011; Nweke et al., 2013). Ojeniyi and Adegboyega (2003) reported that goat manure significantly increased growth and yield of okra, amaranthus, celosia and maize in south western Nigeria. Goat manure was also found to be an efficient source of N, P, K, Ca, Mg and organic matter for pepper, cassava and okra (Awodun et al., 2007; Odedina et al., 2011; Nweke et al., 2013). Studies by Smith and Ayenigbara (2001) and Ojeniyi and Adegboyega (2003) indicated that GM improved N, P, K, Ca and Mg status of soil. Application of GM to $\mathrm{P}$ fixing soils in South Africa was reported to have reduced the sorption of added $\mathrm{P}$ and this effect was largely attributed to the liming potential of GM (Gichangi \& Mnkeni, 2009). The objective of this study was to evaluate the effectiveness of single and double split applications of ground goat manure at varied rates on some chemical properties of the soil, and agronomic performance of sweet maize in Calabar, a tropical rain forest zone.

\section{Materials and Methods}

The experiment was conducted under field conditions during the late growing season from September to December 2012 at the Teaching and Research Farm of the Department of Crop Science, University of Calabar. Calabar is located along the humid coastal region of south eastern Nigeria $\left(4^{\circ} 57^{\prime} \mathrm{N}, 8^{\circ} 19^{\prime} \mathrm{E}\right.$; $37 \mathrm{~m}$ elevation). The region is characterized by a bimodal rainfall distribution ranging from $3000-3500 \mathrm{~mm}$ per year with a long rainy season which starts in March while the short rainy season extends from September-November after a short dry spell of one to two weeks in August. The dry spell often marks the end of the early growing season and the subsequent commencement of the late growing season. The dry season is usually from December to February. The mean annual temperature ranges from 27 to $35{ }^{\circ} \mathrm{C}$ (Iloeje, 2001). The soil is acidic and is classified as Ultisol, characterized by low $\mathrm{pH}$, and usually deficient in multiple nutrients (Brady \& Weil, 2008). The experiment evaluated the response of sweet maize "Tropical Zea" (TZ) obtained from International Institute of Tropical Agricultural (IITA) Ibadan, to two types of goat manure (GM) applications (single and double split doses), five rates of GM $\left(0,5,10,15\right.$ and $\left.20 \mathrm{t} \mathrm{ha}^{-1}\right)$ and $400 \mathrm{~kg} \mathrm{ha}^{-1}$ NPK fertilizer with recommended rates of 120-60-60 $\mathrm{kg} \mathrm{ha}^{-1}$. Factorial combinations of the treatments were laid out in a randomized complete block design with three replicates. Soil samples were collected from the site at $0-30 \mathrm{~cm}$ depths prior to manure application and analyzed for physico-chemical properties to determine the base line fertility status of the site (IITA, 1982). Composite sample of the manure was air-dried, crushed, sieved and analyzed for chemical properties as described in IITA (1982). Another set of soil sample was taken at the end of the growing season to determine the post-harvest soil chemical properties. The relevant results of the physical and chemical analyses of the soil and manure are summarized in Table 1 . The site was cleared of vegetation, ploughed to a depth of $20 \mathrm{~cm}$ and demarcated into three blocks of 12 plots each. Each plot size was $1.5 \times 4.2 \mathrm{~m}\left(6.3 \mathrm{~m}^{2}\right)$, and the net plot size was $1.0 \times 1.8 \mathrm{~m}\left(1.8 \mathrm{~m}^{2}\right)$. Plots were separated by a lane of $1 \mathrm{~m}$ while blocks were kept at a distance of $1.5 \mathrm{~m}$ between them. Sowing was done on tilled flat beds on 16 September 2012. Three seeds were sown per stand at a spacing of $25 \times 60 \mathrm{~cm}$ and thinning of seedlings to one per stand was carried out two weeks after sowing (WAS) to give 42 stands/plot and 66,666 plants per hectare. The goat manure used was cured by air drying for 30 days, ground with a Wiley Mill and incorporated into the soil of the replicated plots in a single and double split doses per treatment, one week before planting. The second split dose of manure was ring applied 10-15 cm away from 
each crop at 5WAS. NPK 15:15:15 fertilizer at the rate of $400 \mathrm{~kg} \mathrm{ha}^{-1}$ was first applied as single dose to all the plots except the control plots one week after crop emergence and urea fertilizer at the rate of $130 \mathrm{~kg} \mathrm{ha}^{-1}$ was used for top-dressing at 5 WAS. Manual weeding was done twice at 2 and 5 WAS by hand pulling and hoeing. Harvesting took place at two stages - milk or soft dough stage (green harvest) and fully mature stage. Green harvesting was done 74 days after sowing from 6 randomly selected plants in the net plot area as indicated by the dying and browning of the silk, fullness of the tip kennels and firmness of the whole husked green ears. The fully mature ears were harvested 90 days after sowing from the remaining 6 plants in the net plot area and sun-dried to $14 \%$ moisture content determined with an Offering Ohaus moisture analyzer model MB54. From these 12 sampled plants, the following parameters were determined: plant height, number of leaves/plant, leaf area index, number of days to $50 \%$ tasselling and silking, total dry matter, number of ears/plant, number of grains/ear, weights of whole green and dehusked green ears, weight of grains/ear and total grain yield. Data generated were subjected to analysis of variance using Genstat Release 7.22 DE Statistical software (Lawes Agricultural Trust, 2008). Differences between treatment mean values were compared using the Least Significant Difference (LSD) at $5 \%$ level of probability.

Table 1. Physico-chemical properties of the top $0-30 \mathrm{~cm}$ depths of the experimental soil and chemical composition of the goat manure used

\begin{tabular}{|c|c|c|c|}
\hline \multirow{2}{*}{$\begin{array}{c}\text { Composition } \\
\text { Physical composition (\%) }\end{array}$} & \multirow[t]{2}{*}{ Soil } & \multirow{2}{*}{\multicolumn{2}{|c|}{$\begin{array}{c}\text { Goat manure } \\
\text { Chemical composition }\end{array}$}} \\
\hline & & & \\
\hline & 85.2 & $\mathrm{pH}$ in $\left(\mathrm{H}_{2} \mathrm{O}\right)(1: 2.5)$ & 8.00 \\
\hline Silt & 2.6 & Organic matter $\left(\mathrm{g} \mathrm{kg}^{-1}\right)$ & 484.12 \\
\hline Clay & 12.2 & Total N $\left(\mathrm{g} \mathrm{kg}^{-1}\right)$ & 19.8 \\
\hline Textural class & Loamy sand & Av. $\mathrm{P}\left(\mathrm{mg} \mathrm{kg}^{-1}\right)$ & 2001.10 \\
\hline Chemical characteristics & & $\mathrm{C} / \mathrm{N}$ & 14.51 \\
\hline $\mathrm{pH}\left(\mathrm{H}_{2} \mathrm{O}\right)(1: 2.5)$ & 5.50 & $\mathrm{Ca}\left(\mathrm{cmol} \mathrm{kg}^{-1}\right)$ & 2600.00 \\
\hline Organic Matter $\left(\mathrm{g} \mathrm{kg}^{-1}\right)$ & 16.75 & $\mathrm{Mg}\left(\mathrm{cmol} \mathrm{kg}^{-1}\right)$ & 677.20 \\
\hline Available P $\left(\mathrm{mg} \mathrm{kg}^{-1}\right)$ & 32.39 & $\mathrm{~K}\left(\mathrm{cmol} \mathrm{kg}{ }^{-1}\right)$ & 4310.00 \\
\hline Total N $\left(\mathrm{g} \mathrm{kg}^{-1}\right)$ & 0.70 & & \\
\hline \multicolumn{4}{|l|}{ Exchangeable bases $\left(\mathrm{cmol} \mathrm{kg}^{-1}\right)$} \\
\hline $\mathrm{Ca}$ & 3.08 & & \\
\hline $\mathrm{Mg}$ & 1.11 & & \\
\hline K & 0.15 & & \\
\hline $\mathrm{Na}$ & 0.07 & & \\
\hline EA & 1.76 & & \\
\hline CEC & 6.16 & & \\
\hline $\mathrm{BS}\left(\mathrm{g} \mathrm{kg}^{-1}\right)$ & 715.91 & & \\
\hline
\end{tabular}

$\mathrm{BS}=$ Base Saturation

\section{Results}

\subsection{Effects of Number and Rate of GM Applications on Soil Chemical Properties}

The post-harvest soil chemical properties as influenced by number and rates of GM application is presented in Table 2. The application of GM significantly $(\mathrm{P} \leq 0.05)$ increased soil $\mathrm{pH}, \mathrm{OM}$ content, total $\mathrm{N}$, available $\mathrm{P}$, exchangeable cations ( $\mathrm{K}, \mathrm{Ca}$ and $\mathrm{Mg}$ ) and cation exchangeable capacity (CEC). Increasing rates of GM equally reduced significantly the exchangeable acidity (EA) of the soil (Table 2). Values of soil $\mathrm{pH}$ and OM content were highest at $20 \mathrm{t} \mathrm{ha}^{-1} \mathrm{GM}$ rate, while the control plots had the lowest, followed by the NPK fertilized plots. The soil $\mathrm{pH}$ at $20 \mathrm{t} \mathrm{ha}^{-1} \mathrm{GM}$ rate, was $32.3 \%$ higher than that of the control plots, while increasing the GM rates from 0 to $5,10,15$ and $20 \mathrm{tha}^{-1}$, resulted in corresponding increases in soil OM content by 132.3, 145.6, 249.6 and 275.6\% respectively. Nitrogen levels increased from $0.70 \mathrm{~g} \mathrm{~kg}^{-1}$ (initial $\mathrm{N}$ status of soil) to 1.8 and $1.9 \mathrm{~g} \mathrm{~kg}^{-1}$ in GM amended plots at $20 \mathrm{t} \mathrm{ha}^{-1}$ rate and NPK fertilizer treatment respectively. There was no significant difference in 
the residual $\mathrm{N}$ values at $20 \mathrm{tha}^{-1} \mathrm{GM}$ rate and the NPK treatment. Soil available $\mathrm{P}$ increased with each increment in GM rate up to the highest rate $\left(20 \mathrm{tha}^{-1}\right)$. The 5, 10, 15 and $20 \mathrm{tha}^{-1} \mathrm{GM}$ rates and NPK fertilizer treatment increased residual $\mathrm{P}$ by $13.1,17.8,33.7,54.7$ and $52 \%$ respectively, over the $0 \mathrm{t} \mathrm{ha}^{-1}$ plots. The increase in residual $\mathrm{K}$ was more pronounced in NPK fertilized plots which was $10.3 \%$ higher than that at $20 \mathrm{tha}^{-1} \mathrm{GM}$ amended plots. Each incremental rate of GM significantly increased residual soil $\mathrm{Ca}$ and $\mathrm{Mg}$ levels and the CEC up to the highest rate with the control plots recording the lowest value. The magnitude of the reduction in soil exchangeable acidity (EA) increased with increasing rates of GM application and peaked at $20 \mathrm{tha}^{-1}$ rate. The EA was reduced from $1.76 \mathrm{cmol} \mathrm{kg}^{-1}$ (initial soil test value) to $0.6 \mathrm{cmol} \mathrm{kg}^{-1}$ at the $20 \mathrm{t} \mathrm{ha}^{-1} \mathrm{GM}$ rate which was more than $2 \frac{1}{2}$ times lower than the initial soil test value (Tables 1 and 2).

Table 2. Effects of number and rate of goat manure application on soil chemical properties in Calabar

\begin{tabular}{|c|c|c|c|c|c|c|c|c|c|}
\hline Treatment & $\mathbf{p H}$ & $O M\left(\mathrm{gkg}^{-1}\right)$ & $\begin{array}{c}\text { Total N } \\
\left(\mathrm{gkg}^{-1}\right)\end{array}$ & Av.P $\left(\mathbf{m g k g}^{-1}\right)$ & $\mathbf{K}$ & $\begin{array}{c}\mathbf{C a} \\
-\mathbf{c}\end{array}$ & $\begin{array}{c}\text { Mg } \\
\text { molkg }^{-1}\end{array}$ & $\mathbf{E A}$ & CEC \\
\hline \multicolumn{10}{|l|}{ GM $\left(\right.$ tha $\left.^{-1}\right)$} \\
\hline 0 & $5.45 \mathrm{~d}$ & $14.53 \mathrm{e}$ & $0.50 \mathrm{e}$ & $30.37 d$ & $0.12 \mathrm{e}$ & $2.49 \mathrm{e}$ & $0.89 \mathrm{e}$ & $1.88 \mathrm{a}$ & $6.28 \mathrm{f}$ \\
\hline 5 & $6.95 b$ & $33.75 d$ & $1.10 \mathrm{~d}$ & $34.34 \mathrm{c}$ & $0.13 \mathrm{e}$ & $4.29 \mathrm{~d}$ & $1.68 \mathrm{~d}$ & $0.92 \mathrm{c}$ & $7.85 \mathrm{~d}$ \\
\hline 10 & $7.03 b$ & $35.68 \mathrm{c}$ & $1.35 \mathrm{c}$ & $35.76 \mathrm{c}$ & $0.17 \mathrm{~d}$ & $5.34 \mathrm{c}$ & $2.00 \mathrm{c}$ & $0.84 \mathrm{~d}$ & $8.92 \mathrm{c}$ \\
\hline 15 & $7.20 \mathrm{a}$ & $50.80 \mathrm{~b}$ & $1.65 \mathrm{~b}$ & $40.60 \mathrm{~b}$ & $0.24 \mathrm{c}$ & $5.97 b$ & $2.30 \mathrm{~b}$ & $0.73 \mathrm{e}$ & $9.52 b$ \\
\hline 20 & $7.21 \mathrm{a}$ & $54.58 \mathrm{a}$ & $1.80 \mathrm{a}$ & $46.98 \mathrm{a}$ & $0.29 b$ & $6.95 \mathrm{a}$ & $2.60 \mathrm{a}$ & $0.64 \mathrm{f}$ & $9.81 \mathrm{a}$ \\
\hline $400 \mathrm{~kg} \mathrm{ha}^{-1} \mathrm{NPK}$ & $6.02 \mathrm{c}$ & $33.53 \mathrm{~d}$ & $1.90 \mathrm{a}$ & $46.16 \mathrm{a}$ & $0.32 \mathrm{a}$ & $4.12 \mathrm{~d}$ & $1.60 \mathrm{~d}$ & $1.77 \mathrm{~b}$ & $7.56 \mathrm{e}$ \\
\hline LSD (0.05) & 0.13 & 0.56 & 0.20 & 3.96 & 0.03 & 0.18 & 0.17 & 0.08 & 0.09 \\
\hline \multicolumn{10}{|c|}{ No. of Application } \\
\hline Single dose & $7.11 \mathrm{a}$ & $42.88 \mathrm{a}$ & $1.23 \mathrm{~b}$ & $36.02 \mathrm{a}$ & $0.13 \mathrm{a}$ & $4.69 \mathrm{~b}$ & $1.68 \mathrm{~b}$ & $1.01 \mathrm{a}$ & $8.15 b$ \\
\hline Double dose & $7.02 b$ & $40.83 b$ & $1.53 \mathrm{a}$ & $33.71 \mathrm{~b}$ & $0.16 \mathrm{~b}$ & $5.03 \mathrm{a}$ & $2.01 \mathrm{a}$ & $0.79 b$ & $9.25 \mathrm{a}$ \\
\hline LSD (0.05) & 0.07 & 0.32 & 0.10 & 2.13 & 0.02 & 0.11 & 0.10 & 0.01 & 0.02 \\
\hline \multicolumn{10}{|l|}{ Interaction } \\
\hline GM x NA & NS & $* *$ & $* *$ & NS & NS & $* *$ & $* *$ & NS & NS \\
\hline
\end{tabular}

Table 3. Interaction effects between number and rate of goat manure application on organic matter, total N, Ca and $\mathrm{Mg}$ contents of the soil in Calabar

\begin{tabular}{|c|c|c|c|c|c|c|c|c|}
\hline \multirow{3}{*}{$\begin{array}{c}\text { Treatment } \\
\text { GM }\left(\text { tha }^{-1}\right) \\
0\end{array}$} & \multicolumn{2}{|c|}{$\begin{array}{c}\text { Number of } \\
\text { application } \\
\text { Single Double }\end{array}$} & \multicolumn{2}{|c|}{$\begin{array}{c}\text { Number of } \\
\text { application } \\
\text { Single Double }\end{array}$} & \multicolumn{2}{|c|}{$\begin{array}{c}\text { Number of } \\
\text { application } \\
\text { Single Double }\end{array}$} & \multicolumn{2}{|c|}{$\begin{array}{c}\text { Number of } \\
\text { application } \\
\text { Single Double }\end{array}$} \\
\hline & \multicolumn{2}{|c|}{$\begin{array}{c}\text { Organic matter (g } \\
\left.\text { kg }^{-1}\right)\end{array}$} & \multicolumn{2}{|c|}{ Total N $\left(\mathrm{g} \mathrm{kg}^{-1}\right)$} & \multicolumn{2}{|c|}{$\mathrm{Ca} \mathrm{cmol} \mathrm{kg}{ }^{-1}$} & \multicolumn{2}{|c|}{ Mg cmol kg-1 } \\
\hline & $14.73 \mathrm{~g}$ & $14.33 \mathrm{~g}$ & $0.50 \mathrm{f}$ & $0.50 \mathrm{f}$ & $2.48 \mathrm{~h}$ & $2.50 \mathrm{~h}$ & $0.88 \mathrm{~h}$ & $0.90 \mathrm{~h}$ \\
\hline 5 & $34.11 \mathrm{e}$ & $33.39 \mathrm{f}$ & $1.00 \mathrm{e}$ & $1.20 \mathrm{de}$ & $3.70 \mathrm{~g}$ & $4.88 \mathrm{e}$ & $1.48 \mathrm{~g}$ & $1.88 \mathrm{ef}$ \\
\hline 10 & $35.88 \mathrm{~d}$ & $35.48 \mathrm{~d}$ & $1.10 \mathrm{e}$ & $1.60 \mathrm{bc}$ & $5.26 \mathrm{~d}$ & $5.42 \mathrm{~d}$ & $1.80 \mathrm{f}$ & $2.20 \mathrm{~cd}$ \\
\hline 15 & $51.40 \mathrm{~b}$ & $50.20 \mathrm{c}$ & $1.40 \mathrm{~cd}$ & $1.90 \mathrm{a}$ & $5.79 \mathrm{c}$ & $6.15 b$ & $2.06 \mathrm{de}$ & $2.54 \mathrm{~b}$ \\
\hline 20 & $57.68 \mathrm{a}$ & $51.48 \mathrm{~b}$ & $1.60 \mathrm{bc}$ & $2.0 \mathrm{a}$ & $6.85 \mathrm{a}$ & $7.05 \mathrm{a}$ & $2.40 \mathrm{bc}$ & $2.80 \mathrm{a}$ \\
\hline $\begin{array}{l}400 \mathrm{~kg} \mathrm{ha}^{-1} \\
\text { NPK }\end{array}$ & $33.83 \mathrm{ef}$ & $33.23 \mathrm{f}$ & $1.80 \mathrm{ab}$ & $2.0 \mathrm{a}$ & $4.04 \mathrm{f}$ & $4.20 \mathrm{f}$ & $1.48 \mathrm{~g}$ & $1.72 \mathrm{fg}$ \\
\hline LSD (0.05) & \multicolumn{2}{|c|}{0.79} & \multicolumn{2}{|c|}{0.30} & \multicolumn{2}{|c|}{0.26} & \multicolumn{2}{|c|}{0.24} \\
\hline
\end{tabular}


The effect of number of GM application (NA) was equally significant for all the soil attributes determined. The single application of GM and the NPK treatment recorded higher levels of soil $\mathrm{pH}, \mathrm{OM}$ content, $\mathrm{P}$ and EA than the double split doses, while the reverse was the case for residual soil $\mathrm{N}, \mathrm{K}, \mathrm{Ca}, \mathrm{Mg}$ and CEC in which the double split application recorded higher values. The double split doses of GM and NPK fertilizer increased soil $\mathrm{N}, \mathrm{K}, \mathrm{Ca}, \mathrm{Mg}$ and CEC levels by 24.4, 23.1, 7.3, 19.6 and $13.50 \%$; and lowered the EA by $27.9 \%$ over the single application (Table 2).

The NA $\times$ GM and NPK fertilizer interaction effects were highly significant for OM, total N, exchangeable Ca and $\mathrm{Mg}$ (Tables 2 and 3). The double split application of GM at $20 \mathrm{t} \mathrm{ha}^{-1}$, recorded the highest values for residual soil $\mathrm{Ca}$ and $\mathrm{Mg}$ while the single application of GM at $20 \mathrm{tha}^{-1}$ rate produced the highest soil OM content (Table $3)$.

\subsection{Effects of Number and Rate of GM Applications on Sweet Maize Performance}

Tables 4 and 5 present the influence of number of GM application and rates on vegetative and reproductive attributes of sweet maize. The effect of GM and NPK fertilizer on all the vegetative attributes, were all significant. Values obtained for plant height and number of leaves/plant were highest at the NPK fertilizer treatment but not significantly different from those obtained at the 15 and $20 \mathrm{t} \mathrm{ha}^{-1} \mathrm{GM}$ rates (Table 4). Each increment in GM rate, significantly increased the leaf area index (LAI), but the NPK fertilized plots maximized LAI more than any GM treatment. The number of days to $50 \%$ tasselling and silking did not differ significantly at 15 and $20 \mathrm{tha}^{-1} \mathrm{GM}$ rates and the NPK fertilized plots, but were all significantly lower than the other treatments. There was no significant difference between the total dry matter (TDM) yield at $20 \mathrm{tha}^{-1} \mathrm{GM}$ rate and NPK fertilizer treatment. For all the variables mentioned above, the $0 \mathrm{t} \mathrm{ha}^{-1} \mathrm{GM}$ rate recorded the least values (Table 4). The effect of the number of GM application (NA) was equally significant for all vegetative attributes. The double split doses of GM and NPK fertilizer treatment out-performed the single dose application in terms of plant height, number of leaves/plant, LAI, number of days to $50 \%$ tasselling and silking and TDM production (Table 4).

Table 4. Effects of number and rate of goat manure application on plant height $(\mathrm{cm})$, number of leaves/plant, leaf area index (LAI), number of days to 50\% tasselling and silking and total dry matter (TDM) production of sweet maize in Calabar

\begin{tabular}{|c|c|c|c|c|c|c|}
\hline Treatment & $\begin{array}{l}\text { Plant height } \\
\text { (cm) }\end{array}$ & $\begin{array}{c}\text { No of } \\
\text { leaves/plant }\end{array}$ & LAI & $\begin{array}{c}\text { Days to } 50 \% \\
\text { tasselling }\end{array}$ & $\begin{array}{c}\text { Days to } 50 \% \\
\text { silking }\end{array}$ & $\begin{array}{c}\text { Total dry matter } \\
\text { (g/plant) }\end{array}$ \\
\hline \multicolumn{7}{|l|}{ GM $\left(\right.$ tha $\left.^{-1}\right)$} \\
\hline 0 & $134.83 d$ & $8.50 \mathrm{c}$ & $2.64 \mathrm{e}$ & $57.83 \mathrm{a}$ & $66.18 \mathrm{a}$ & $102.48 \mathrm{e}$ \\
\hline 5 & $143.33 \mathrm{~cd}$ & $9.50 \mathrm{~b}$ & $2.93 \mathrm{~d}$ & $57.17 \mathrm{ab}$ & $65.83 \mathrm{ab}$ & $114.69 \mathrm{~d}$ \\
\hline 10 & $146.17 \mathrm{bc}$ & $9.83 \mathrm{ab}$ & $2.97 \mathrm{~cd}$ & $56.50 \mathrm{bc}$ & $65.00 \mathrm{bc}$ & $178.63 \mathrm{c}$ \\
\hline 15 & $154.17 \mathrm{ab}$ & $9.83 \mathrm{ab}$ & $3.08 \mathrm{c}$ & $56.33 \mathrm{bc}$ & $64.83 \mathrm{~cd}$ & $196.66 \mathrm{~b}$ \\
\hline 20 & $156.67 \mathrm{ab}$ & $10.17 \mathrm{a}$ & $3.49 \mathrm{~b}$ & $55.83 \mathrm{c}$ & $64.17 \mathrm{~cd}$ & $211.30 \mathrm{a}$ \\
\hline $\begin{array}{l}400 \mathrm{~kg} \mathrm{ha}^{-1} \\
\text { NPK }\end{array}$ & $163.50 \mathrm{a}$ & $10.00 \mathrm{a}$ & $4.32 \mathrm{a}$ & $55.67 \mathrm{c}$ & $64.00 \mathrm{~d}$ & $209.69 \mathrm{a}$ \\
\hline LSD (0.05) & 10.83 & 0.56 & 0.12 & 0.88 & 0.84 & 10.59 \\
\hline \multicolumn{7}{|c|}{ No. of Application } \\
\hline Single dose & $142.06 \mathrm{~b}$ & $9.28 \mathrm{~b}$ & $2.87 \mathrm{~b}$ & $65.87 \mathrm{a}$ & $65.87 \mathrm{a}$ & $159.82 b$ \\
\hline Double dose & $157.50 \mathrm{a}$ & $10.00 \mathrm{a}$ & $3.61 \mathrm{a}$ & $64.17 \mathrm{~b}$ & $64.83 b$ & $177.99 \mathrm{a}$ \\
\hline $\operatorname{LSD}(0.05)$ & 6.25 & 0.32 & 0.07 & 0.51 & 0.49 & 6.11 \\
\hline \multicolumn{7}{|l|}{ Interaction } \\
\hline GM x NA & NS & NS & NS & NS & NS & $* *$ \\
\hline
\end{tabular}

NS $=$ Not significant.

** = Highly significant at $1 \%$ level of probability. 
Table 5. Effects of number and rate of goat manure application on number of ears/plant, number of grains/ear, weight of grains/ear, weights of whole and dehusked green ears and total grain yield of sweet maize in Calabar

\begin{tabular}{|c|c|c|c|c|c|c|}
\hline Treatment & $\begin{array}{c}\text { No. of } \\
\text { ears/plant }\end{array}$ & $\begin{array}{c}\text { No. of } \\
\text { grains/ear }\end{array}$ & $\begin{array}{l}\text { Wt. of whole } \\
\text { green ear (g) }\end{array}$ & $\begin{array}{l}\text { Wt. of dehusked } \\
\text { green ear (g) }\end{array}$ & $\begin{array}{c}\text { Wt. of } \\
\text { grains/ear (g) }\end{array}$ & $\begin{array}{l}\text { Total grain } \\
\text { yield }\left(\text { tha }^{-1}\right)\end{array}$ \\
\hline \multicolumn{7}{|l|}{ GM $\left(\right.$ tha $\left.^{-1}\right)$} \\
\hline 0 & $1.01 \mathrm{~b}$ & $238.5 d$ & $113.69 \mathrm{~d}$ & $72.04 d$ & $45.86 \mathrm{c}$ & $1.62 \mathrm{~b}$ \\
\hline 5 & $1.02 \mathrm{~b}$ & $278.00 \mathrm{c}$ & $245.00 \mathrm{c}$ & $86.85 \mathrm{c}$ & $53.44 \mathrm{c}$ & $2.38 \mathrm{~b}$ \\
\hline 10 & $1.17 \mathrm{~b}$ & $284.33 c$ & $315.18 b$ & $90.72 c$ & $70.91 b$ & $3.43 \mathrm{a}$ \\
\hline 15 & $1.17 \mathrm{~b}$ & $340.50 \mathrm{bc}$ & $383.56 \mathrm{a}$ & $111.35 b$ & $74.03 \mathrm{~b}$ & $3.58 \mathrm{a}$ \\
\hline 20 & $1.33 \mathrm{ab}$ & $395.17 \mathrm{ab}$ & $395.22 \mathrm{a}$ & $144.52 \mathrm{a}$ & $92.01 \mathrm{a}$ & $3.68 \mathrm{a}$ \\
\hline $\begin{array}{l}400 \mathrm{~kg} \mathrm{ha}^{-1} \\
\text { NPK }\end{array}$ & $1.67 \mathrm{a}$ & $430.33 a$ & $422.58 \mathrm{a}$ & $154.61 \mathrm{a}$ & $89.17 \mathrm{a}$ & $3.89 \mathrm{a}$ \\
\hline LSD (0.05) & 0.45 & 75.67 & 43.23 & 10.80 & 8.38 & 0.86 \\
\hline \multicolumn{7}{|l|}{$\mathbf{N A}$} \\
\hline Single dose & 1.11 & $277.33 b$ & $299.04 b$ & $101.48 b$ & $76.76 \mathrm{~b}$ & $2.90 \mathrm{~b}$ \\
\hline Double dose & 1.33 & $329.83 a$ & $326.04 \mathrm{a}$ & $118.55 \mathrm{a}$ & $92.97 \mathrm{a}$ & $3.30 \mathrm{a}$ \\
\hline LSD (0.05) & NS & 43.69 & 24.96 & 6.24 & 4.84 & 0.37 \\
\hline \multicolumn{7}{|l|}{ Interaction } \\
\hline GM x NA & NS & NS & $* *$ & $*$ & NS & $* *$ \\
\hline
\end{tabular}

The highest number of ears/plant, grains/ear and heaviest dehusked green ear $(1.7,430.3$ and $154.6 \mathrm{~g})$ were obtained from maize crop at the NPK treatment which however, was not significantly different from the $20 \mathrm{t}^{-1}$ GM rate (Table 5). The NPK fertilized plots equally maximized weight of whole green ear even though this was not significantly different from those obtained at 15 and $20 \mathrm{t} \mathrm{ha}^{-1} \mathrm{GM}$ rates. Weight of grains/ear peaked at $20 \mathrm{t}$ $\mathrm{ha}^{-1} \mathrm{GM}$ rate but did not differ significantly from the value obtained at the NPK treatment. Total grain yield obtained at 10, 15 and $20 \mathrm{t} \mathrm{ha}^{-1}$ GM rates with that of NPK treatment did not differ significantly but the value at the NPK fertilized plots were however the highest. The NPK fertilizer treatment gave grain yield increases of 5.7, 8.7, 13.4, 63.5 and $140.1 \%$ above the $20,15,10,5$ and $0 \mathrm{t} \mathrm{ha}^{-1} \mathrm{GM}$ rates respectively, which was in the order of NPK treatment $>20>15>10>5>0 \mathrm{tha}^{-1} \mathrm{GM}$ rates. The effect of number of GM applications was significant for number of grains/ear, weights of whole and dehusked green ears, weight of grains/ear and total grain yield. The double split doses of GM rates significantly increased these variables above the sole application. The number of grains/ear, weight of grains/ear, weight of dehusked green ear and total grain yield obtained with the double split application of GM were 18.9, 21.1, 16.8 and 13.8\% respectively, higher than those of the single application of GM (Table 5).

The NA $x$ GM and NPK fertilizer interaction effects were significant $(\mathrm{P}=0.05)$ for weight of dehusked green ear and highly significant $(\mathrm{P}=0.01)$ for total dry matter, weight of whole green ear and total grain yield (Tables 4 and 5). The double split application of NPK fertilizer, gave the highest values for the attributes mentioned but these values were not significantly different from those obtained at 15 and $20 \mathrm{t} \mathrm{ha}^{-1} \mathrm{GM}$ rates when split applied twice for TDM, weight of whole green ear and total grain yield (Table 6). 
Table 6. Interaction effects between number and rate of goat manure application on total dry matter (g/plant), whole and dehusked green ear weights $(\mathrm{g})$ and total grain yield $\left(\right.$ tha $\left.^{-1}\right)$ of sweet maize in Calabar

\begin{tabular}{|c|c|c|c|c|c|c|c|c|}
\hline \multirow[t]{2}{*}{ Treatment } & \multicolumn{2}{|c|}{$\begin{array}{l}\text { Number of } \\
\text { application }\end{array}$} & \multicolumn{2}{|c|}{$\begin{array}{l}\text { Number of } \\
\text { application }\end{array}$} & \multicolumn{2}{|c|}{$\begin{array}{l}\text { Number of } \\
\text { application }\end{array}$} & \multicolumn{2}{|c|}{$\begin{array}{l}\text { Number of } \\
\text { application }\end{array}$} \\
\hline & Single & Double & Single & Double & Single & Double & Single & Double \\
\hline GM $\left(\right.$ tha $\left.^{-1}\right)$ & \multicolumn{2}{|c|}{ Total dry matter } & \multicolumn{2}{|c|}{ Wt. of whole green ear } & \multicolumn{2}{|c|}{$\begin{array}{c}\text { Wt. of dehusked green } \\
\text { ear }\end{array}$} & \multicolumn{2}{|c|}{ Total grain yield } \\
\hline 0 & $93.65 \mathrm{e}$ & $111.31 \mathrm{~cd}$ & $115.85 \mathrm{f}$ & $111.53 \mathrm{f}$ & $72.60 \mathrm{f}$ & $71.47 \mathrm{f}$ & $1.46 \mathrm{f}$ & $1.78 \mathrm{ef}$ \\
\hline 5 & $103.68 \mathrm{de}$ & $125.70 \mathrm{c}$ & $237.81 \mathrm{~b}$ & $252.18 \mathrm{e}$ & $78.01 \mathrm{f}$ & $95.69 \mathrm{e}$ & $2.11 \mathrm{e}$ & $2.65 d$ \\
\hline 10 & $172.01 \mathrm{~b}$ & $185.24 b$ & $289.67 \mathrm{de}$ & $340.68 \mathrm{~cd}$ & $80.37 f$ & $101.07 \mathrm{e}$ & $3.18 \mathrm{c}$ & $3.68 \mathrm{~b}$ \\
\hline 15 & $181.18 \mathrm{~b}$ & $212.13 \mathrm{a}$ & $370.79 \mathrm{dc}$ & $396.33 \mathrm{abc}$ & $99.57 \mathrm{e}$ & $123.13 d$ & $3.43 \mathrm{bc}$ & $3.73 \mathrm{ab}$ \\
\hline 20 & $205.92 \mathrm{a}$ & $216.69 a$ & $378.83 \mathrm{bc}$ & $411.61 \mathrm{ab}$ & $136.73 \mathrm{c}$ & $152.31 b$ & $3.57 \mathrm{bc}$ & $3.79 \mathrm{ab}$ \\
\hline $\begin{array}{l}400 \mathrm{~kg} \mathrm{ha}^{-1} \\
\text { NPK }\end{array}$ & $202.49 a$ & $216.88 \mathrm{a}$ & $401.26 \mathrm{abc}$ & $443.90 \mathrm{a}$ & $141.57 \mathrm{bc}$ & $167.64 a$ & $3.63 b$ & $4.15 \mathrm{a}$ \\
\hline LSD (0.05) & \multicolumn{2}{|c|}{14.97} & \multicolumn{2}{|c|}{61.13} & \multicolumn{2}{|c|}{15.28} & \multicolumn{2}{|c|}{0.45} \\
\hline
\end{tabular}

\section{Discussion}

The increases in soil nutrients due to GM application were probably due to the OM and nutrient contents of the manure (Table 1). The high $\mathrm{Ca}$ content of the GM was probably responsible for the relatively high $\mathrm{pH}$ in amended plots (Mbah \& Mbagwu, 2006). In addition, during microbal decomposition of incorporated manures, basic cations are released which would raise the initial $\mathrm{pH}$ of the soil to a more favourable level for crop production (Pucknee \& Summer, 1997). The increase in soil available N, P, and K with application rates of GM could be attributed to increased microbial activitiy as a result of enhanced decomposition of the organic forms of N, P, and K. Earlier studies by Smith and Ayenigbara (2001); Ano and Ubochi (2007) had shown that GM improved N, P, K, Ca, Mg and CEC status of soil and also reduced the exchangeable acidity (EA) of soil. Positive changes in soil contents of $\mathrm{K}, \mathrm{Ca}$ and $\mathrm{Mg}$ and reduction in values of $\mathrm{EA}$ accompanied by increases in CEC upon application of animal manures have been documented by other workers (Ano \& Ubochi, 2007; Uwah et al., 2012).

All the growth and yield parameters were significantly and positively responsive to increasing rates of GM and NPK fertilizer split applied twice. The low fertility status of the site which was in continuous cropping without fertilizer application made the response of sweet maize to GM and NPK fertilizer treatments apparent. Goat manure at higher rates $\left(15\right.$ and $\left.20 \mathrm{t} \mathrm{ha}^{-1}\right)$ promoted better growth probably as a result of higher uptake of inherent nutrients in the manure as compared to lower rates. The highest values for the vegetative attributes recorded for the inorganic fertilizers relative to GM are attributable to the fact that GM generally contains low quantities of plant nutrients which are usually released slowly. These nutrients triggered the vigorous growth of plant, thereby achieving higher LAI and further boosted the dry matter production and hastened the flowering and maturity period. Dry matter yield was highly related to soil availability of $\mathrm{N}, \mathrm{P}$ and $\mathrm{K}$ and the narrow $\mathrm{C} / \mathrm{N}$ ratio suggested quicker mineralization of organic forms of N, P and K (Maerere et al., 2001). These results therefore, suggest that the observed response was largely due to increased availability of nutrients supplied by GM which resulted in enhanced root growth. Superior growth attributes obtained with high rates of GM in this study, have been reported by other workers (Ojeniyi \& Adegboyega, 2003; Awodun et al., 2007; Akanni \& Ojeniyi, 2008; Odedina et al., 2011; Nweke et al., 2013).

The increase in grain yield with increasing rates of GM up to $20 \mathrm{tha}^{-1}$, was as a result of significant increases in almost all yield contributing characters especially number of ears/plant, number of grains/ear and weight of grains/ear. The increase in grain yield could also be due to the significant increases in number of leaves/plant and LAI which enhanced greater photosynthetic activity and translocation of assimilates. Therefore, the improved nutrient availability as a result of GM application, must have led to the significant enhancement of growth and yield of sweet maize. This result is in conformity with the findings of Ojeniyi and Adegboyega (2003) that GM increased yield of celosia, Bala and Manga (2009) who worked on cabbage and Nweke et al. (2013) on okra.

This study however, found that the NPK fertilizer increased growth and yield of sweet maize better than any GM treatment even though, the increase in values obtained for the various attributes were not significantly different from those at the $20 \mathrm{t} \mathrm{ha}^{-1} \mathrm{GM}$ rate. This is attributable to the quicker release of these $\mathrm{N}, \mathrm{P}$ and $\mathrm{K}$ nutrients from 
the inorganic fertilizers (Smith \& Ayenigbara, 2001). Comparison of the number of applications (single and double-split) indicated that for all the growth and yield attributes, the double-split application produced higher response than the single. This was probably because in single application, most of the soluble nutrients may have been used up by the plant early in the season, volatilized or leached out from the root zone. The split application of the fertilizers and GM however, made the nutrients more beneficial to the plant at various stages of its growth and hence the superior performance recorded. This is in support of the ascertain by Havlin et al. (2006) that nutrients should be applied at a time that will maximize recovery by the crop and reduce potential loses to the environment.

\section{Conclusion}

The study showed that GM improved the chemical properties of the soil and enhanced the growth and yield of sweet maize. The application of GM at $20 \mathrm{t} \mathrm{ha}^{-1}$ was the most effective among the rates investigated in terms of boosting the residual soil nutrients and agronomic performance of sweet maize. Double application of GM and NPK fertilizer were more beneficial to the soil and crop than the single application as indicated by higher growth and yield values obtained. Even though higher values were obtained from NPK treatment for most of the agronomic attributes, these however, were not significantly different from values obtained at $20 \mathrm{tha}^{-1} \mathrm{GM}$ rate. Double-split application of ground GM at $20 \mathrm{t} \mathrm{ha}^{-1}$ is therefore recommended for sweet maize production in this agro-ecology.

\section{References}

Akanni, D. I., \& Ojeniyi, S. O. (2008). Residual effect of goat and poultry manures on soil properties, nutrient content and yield of Amaranthus in Southwest Nigeria. Resh. J. Agronomy, 2(2), 44-47.

Akinrinde, E. A., \& Obigbesan, G. O. (2000). Evaluation of the fertility status of selected soils for crop production in five ecological zones of Nigeria. Proceedings $26^{\text {th }}$ Annual Conference of Soil Science Society of Nigeria, Ibadan, (pp. 279-288).

Ano, A. O., \& Ubochi, C. I. (2007). Neutralization of soil acidity by animal manures: mechanism of reaction. African J. Biotech, 6(4), 364-368.

Awodun, M. A., Omonijo, L. I., \& Ojeniyi, S. O. (2007). Effect of goat dung and NPK fertilizer on soil and leaf nutrient content, growth and yield of pepper. Int'l. J. Soil Sci., 2(2), 142-147. http://dx.doi.org/10.3923/ijss.2007.142.147

Badu-Apraku B., \& Fakorede, M. A. B. (2006). Zea mays L. In M. Brink \& G. Belay (Eds.). Plant Resources of Tropical Africa 1 (pp. 229-237). Cereals and pulses, PROTA Foundation, Wageningen, Netherlands/Backhuys Publishers, Leiden, Netherlands/CTA, Wageningen, Netherlands.

Bala, M. G., \& Manga, A. A. (2009). Evaluating the response of cabbage (Brassica oleracea var. capitata L.) to different types of organic manure. Savannah J. Agriculture, 4, 40-44.

Bhatt, P. S. (2012). Response of sweet corn hybrid to varying plant densities and nitrogen levels. African J. Agric Res, 7(46), 6158-6166.

Brady, N. C., \& Weil, R. R. (2008). The Nature and Properties of Soils (14th ed) (p. 992). Prentice-Hall Inc. New Jersey, USA.

Garg, S., \& Bahla, G. S. (2008). Phosphorus availability to maize as influenced by organic manures and fertilizer $\mathrm{P}$ associated phosphatase activity in soils. Bioresource Tech., 99(13), 5773-5777. http://dx.doi.org/10.1016/j.biortech.2007.10.063

Gichangi, E. M., \& Mnkeni, P. N. S. (2009). Effects of goat manures and lime addition on phosphate sorption by two soils from the Transkei region, South Africa. Commun. Soil Sci. Plant Anal, 40, 3335-3347. http://dx.doi.org/10.1080/00103620903325943

Havlin, J. L., Beaton, J. D., Tisdale, S. L., \& Nelson, W. L. (2006). Soil fertility and fertilizers: An introduction to nutrient management (7th ed) (p. 515). Prentice-Hall of India Private Ltd., New Delhi.

IITA. (1982). Selected methods of soil and plant analysis. International Institute of Tropical Agriculture Manual Series No. 7 Ibadan, Nigeria.

Iloeje, N. P. (2001). A new geography of Nigeria (New revised ed.) (p. 199). Longman Nigeria Plc.

Lawes Agricultural Trust. (2008). GENSTAT Release 7.22 DE Reference Manuel. VSN International, Hemel Hempstead, Hertfordshire, UK. 
Maerere, A. P., Kimbi, G. G., \& Nonga, D. L. M. (2001). Comparative effectiveness of animal manures on soil chemical properties, yield and root growth of Amaranthus (Amaranthus cruentus L.). African J. Sci. Tech, 1(4), 14-21.

Mbah, C. N., \& Mbagwu, S. C. (2006). Effect of animal wastes on physico-chemical properties of a dystric leptosl and maize yield in southern Nigeria. J. Soil Sci., 16, 96-103.

Nweke, I. A., Ijearu, S. I., \& Igili, D. N. (2013). Effect of different sources of animal manure on the growth and yield of okra (Abelmuschus esculentus (L.) Moench) in ustoxic dystropept at Enugu, south eastern Nigeria. Int'l. J. Scientific \& Tech. Res., 2(3), 135-137.

Odedina, J. N., Odedina, S. A., \& Ojeniyi, S. O. (2011). Effect of types of manure on growth and yield of cassava (Manihot esculenta, Crantz). Researcher, 2(5), 1-8.

Ojeniyi, S. O., \& Adegboyega, A. A. (2003). Effect of combined use of urea and goat dung manure on celosia. Nig. Agric. J., 54, 87-90.

Pucknee, S., \& Summer, E. (1997). Cation and nitrogen contents of organic matter determine its liming potential. Soil Sci. Soc. Amer. J., 61, 86-96. http://dx.doi.org/10.2136/sssaj1997.03615995006100010014x

Smith, M. A. K.,\& Ayenigbara, E. A. (2001). Comparative growth and nutrient composition of Indian Spinach in an enriched humid tropical environment. African Crop Sci. Conf. Proceedings, Uganda, 5, 1007-1013.

Uwah, D. F., Ukoha, G. O., \& Iyango, J. (2012). Okra performance and soil and water conservation as influenced by poultry manure and organic mulch amendments. Journal of food, agriculture and environment, 1, 748-754.

\section{Copyrights}

Copyright for this article is retained by the author(s), with first publication rights granted to the journal.

This is an open-access article distributed under the terms and conditions of the Creative Commons Attribution license (http://creativecommons.org/licenses/by/3.0/). 